\title{
Taxonomic Characteristics of a Thermophilic Acidophilic Strain of Bacillus Producing Thermophilic Acidophilic Amylase and Thermostable Xylanase
}

\author{
Fuji UCHINO and Osamu FukudA \\ Department of Agricultural Chemistry, Nagoya University, \\ Chikusa-ku, Nagoya 464, Japan
}

Received September 8, 1982

\begin{abstract}
Taxonomic characteristics of a strain of thermophilic acidophilic bacillus, Bacillus sp. 11-1S, which had the ability to produce thermophilic acidophilic amylase and thermostable xylanase were examined. Cells of the organism were aerobic, heterotrophic, Gram-positive, spore-forming rods. It grew at temperatures between 45 and $70^{\circ} \mathrm{C}$ (optimum $65^{\circ} \mathrm{C}$ ) in media of pHs ranging from 2.0 to 5.0 (optimum 3.5 4.0). Physiological and biochemical characteristics were identical with those of Bacillus acidocaldarius, and \% GC of DNA (59\%) was close to that of the latter $(61 \sim 62 \%)$. From these results it was concluded that the organism belongs to B. acidocaldarius Darland and Brock.
\end{abstract}

In previous works, we have shown that a strain of thermophilic acidophilic bacillus, Bacillus sp. 11-1S, is capable of production of a thermophilic, unusually acidophilic amylase $^{1)}$ and a thermostable xylanase, ${ }^{2)}$ and their enzymatic properties have been characterized. It was of interest to determine the taxonomic position of the bacterium. In the present paper we report the taxonomic characteristics of the organism. It grows at temperatures between 45 and $70^{\circ} \mathrm{C}$ in media of $\mathrm{pHs}$ ranging from 2 to 5 , and is an aerobic, heterotrophic, Grampositive and spore-forming rod. Its characteristics are identical with those of Bacillus acidocaldarius Darland and Brock. ${ }^{3,4,11)}$

\section{MATERIALS AND METHODS}

Bacterial strain. Bacillus sp. 11-1S is one of the bacteria isolated by us from hot-spring waters in the Hokkaido area of Japan. The isolation procedures were similar to those described previously ${ }^{5)}$ except that the enrichment was performed at $65^{\circ} \mathrm{C}$ using the following medium with a $\mathrm{pH}$ of 3.5 . The basal salt medium, to which $0.5 \%$ of glucose and $0.1 \%$ of yeast extract (Difco) were added, was used for the enrichment. The organism had been maintained on an agar slope of the same composition.

Basal salt medium. The basal salt medium consisted of $\mathrm{KH}_{2} \mathrm{PO}_{4} 2 \mathrm{~g}, \mathrm{NaCl} 1 \mathrm{~g}, \mathrm{NH}_{4} \mathrm{Cl} 2 \mathrm{~g}, \mathrm{MgSO}_{4} \cdot 7 \mathrm{H}_{2} \mathrm{O} 0.5 \mathrm{~g}$,
$\mathrm{FeSO}_{4} \cdot 7 \mathrm{H}_{2} \mathrm{O} 25 \mathrm{mg}, \mathrm{MnSO}_{4} 25 \mathrm{mg}, \mathrm{CaCl}_{2} \cdot 2 \mathrm{H}_{2} \mathrm{O} 0.1 \mathrm{~g}$, and distilled water to 1 liter.

Growth experiments. For growth studies, a carbon source (usually glucose, $0.5 \%$ ) was supplemented to the basal salt medium and the medium was adjusted to desired pHs with $3 \mathrm{~N} \mathrm{HCl}$ or $2 \mathrm{~N} \mathrm{NaOH}$. To determine specific growth rate, L-shaped tubes (Monod-type, $100 \times 80 \times 18$ $\mathrm{mm}$ ) containing $6 \mathrm{ml}$ of medium were shaken (70 strokes per $\mathrm{min}$ ) in a constant temperature water bath. In the case of stationary cultures, test bubes $(180 \times 18 \mathrm{~mm})$ containing $5 \mathrm{ml}$ of medium were used. Growth was measured turbidimetrically with an ADS electrophotometer (Fuji Kogyo Co.) withn a No. 660 filter. Specific growth rate was calculated from the data obtained during the exponential phase of growth.

Morphological studies. Morphological properties were examined by conventional methods. ${ }^{6}$

Utilization of carbon compounds. Carbohydrates and other carbon compounds were tested for utilization as the sole source of carbon and energy. The basal salt medium ( $\mathrm{pH} 4.0$ ) supplemented with $0.5 \%$ of the compounds was incubated for 4 days at $65^{\circ} \mathrm{C}$ without shaking.

Physiological and biochemical reactions. Starch hydrolysis was detected by flooding $0.02 \mathrm{~N} \mathrm{I}_{2}$-KI solution over the agar plate of the basal salt medium $(\mathrm{pH} 4.2)$ containing starch $(0.5 \%)$ and peptone (Difco, $0.5 \%$ ) after incubation for 1 and 2 days at $65^{\circ} \mathrm{C}$.

The Voges-Proskauer reaction and indole production were tested according to the methods described ${ }^{6)}$ except 
that the media of a pH of 4.5 were incubated at $65^{\circ} \mathrm{C}$.

The test for nitrate as a source of sole nitrogen was carried out at $65^{\circ} \mathrm{C}$ using the basal salt medium with glucose by replacing $\mathrm{NH}_{4} \mathrm{Cl}$ with $\mathrm{KNO}_{3}$ or $\mathrm{NaNO}_{3}$.

Gelatin hydrolysis was detected by examination at $0^{\circ} \mathrm{C}$

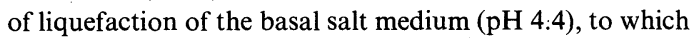
$0.5 \%$ glucose and $15 \%$ gelatin were added, after incubation for 2 days at $65^{\circ} \mathrm{C}$.

For testing anaerobic growth, test tubes containing the basal salt medium supplemented with $0.5 \%$ glucose and $0.1 \%$ yeast extract, in the presence or absence of $0.1 \%$ $\mathrm{KNO}_{3}$, were evacuated and flushed with $\mathrm{N}_{2}$ gas after inoculation. The tubes were incubated for 6 days at $65^{\circ} \mathrm{C}$.

$\% G C$ of $D N A$. DNA was extracted by the methods of Saito and Miura ${ }^{7)}$ and further purified by hydroxyapatite chromatography. ${ }^{8)}$ The guanine-plus-cytosine content $\left(\mathrm{mol}^{\mathrm{o}} \mathrm{)}\right)$ was estimated chromatographically ${ }^{9)}$ after hydrolysis with Nuclease $P_{1}{ }^{10}{ }^{10}$

The other physiological and biochemical tests were performed by conventional methods. ${ }^{6}$ )

Materials. RNase I and RNase $\mathrm{T}_{1}$ were purchased from Worthington Biochemical Crop., Freehold, N.J., USA; hydroxyapatite (DNA-grade Bio-Gel HTP) and ionexchange resin AG 50W-X4 ( -400 mesh) were from BioRad Laboratories, Richmond, CA, USA; Nuclease $P_{1}$ was from Yamasa Shoyu Co., Choshi, Japan; and 5'-deoxymononucleotides were from Sigma Chemical Co., St. Louis, MO, USA. The other chemicals were of analytical grade commercially available.

\section{RESULTS}

\section{Morphology}

The cells of Bacillus sp. 11-1S were Grampositive rods $(0.6 \sim 0.7 \times 1.5 \sim 2.5 \mu \mathrm{m})$, occur-

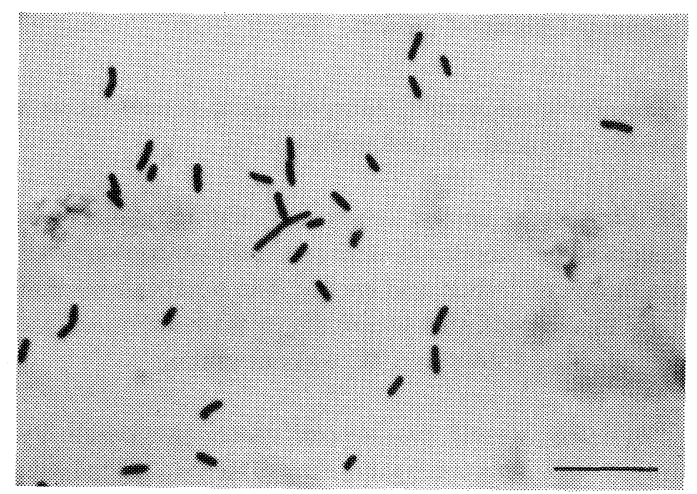

FIG. 1. Photomicrograph of Bacillus sp. 11-1S.

Cells grown in glucose-yeast extract-basal salt medium for $12 \mathrm{hr}$ at $65^{\circ} \mathrm{C}$ without shaking, stained with crystal violet. The scale bar indicates $10 \mu \mathrm{m}$. red singly or in pairs (rarely filamentous), and formed refractile endospores (oval form) located terminally to subterminally. The sporangia were slightly swollen. Heat resistance of the spores was demonstrated by heating for 3 min in boiling water.

On an agar plate of glucose-yeast extractbasal salts after 1 day incubation at $60^{\circ} \mathrm{C}$, the unpigmented colonies were irregular with an undulate margin, convex elevation, smooth surface, translucent and butyrous.

In unaerated broth cultures, membranous surface growth was noted.

\section{Temperature and $\mathrm{pH}$ relationships}

The organism grew in the range from 45 to $70^{\circ} \mathrm{C}$ and at $\mathrm{pHs}$ from 2.0 to 5.0 , but no growth was observed at temperatures of $40^{\circ} \mathrm{C}$ or lower, nor at $\mathrm{pH} 1.5$ or 5.5 . The optimal temeprature and $\mathrm{pH}$ were found to be $65^{\circ} \mathrm{C}$ and $3.5 \sim 4.0$, respectively. In shake cultures, the specific growth rates at $65^{\circ} \mathrm{C}$ and $45^{\circ} \mathrm{C}$ were 1.12 and $0.263\left(\mathrm{hr}^{-1}\right)$, respectively.

\section{Physiological and biochemical reactions}

1) Relation to $\mathrm{O}_{2}$. The organism was aerobic and failed to grow anaerobically in the presence or absence of nitrate.

2) Nitrate reduction. It failed to reduce nitrate to nitrite.

3) Voges-Proskauer reaction. The test was negative.

4) Production of indole. The organism was negative.

5) Hydrolysis of starch. The organism hydrolyzed it considerably.

6) Hydrolysis of gelatin. Liquefaction was observed.

7) Growth-factor requirements. It did not require any growth factors and grew in a medium of basal plus glucose or galactose.

8) Nitrate as nitrogen source. It was unable to utilize nitrate as a sole source of nitrogen.

9) Utilization of carbon compounds. Table I shows that the organism utilized 8 kinds of compounds tested as a source of carbon and energy. Organic acids such as 
Table I. Utilization of Carbon Compounds as Sole Sources of CARbon and EnERGY

Bacillus sp. 11-1S was grown in basal salt medium $(\mathrm{pH}$ 4.0) supplemented with the indicated carbon source $(0.5 \%)$ for 4 days at $65^{\circ} \mathrm{C}$.

\begin{tabular}{lcc}
\hline \multicolumn{1}{c}{ Compound } & $11-1 \mathrm{~S}$ & B. acidocaldarius ${ }^{4)}$ \\
\hline Glucose & $+^{*}$ & + \\
Galactose & + & + \\
Casamino acids $* *$ & + & + \\
Starch & + & + \\
Glycerol & + & + \\
Sucrose & + & + \\
Gluconate & + & + \\
Inositol & - & $\mathrm{v}$ \\
Ribose & - & $\mathrm{v}$ \\
Rhamnose & + & $\mathrm{v}$ \\
Lactose & - & $\mathrm{v}$ \\
Ethanol & - & - \\
Sorbitol & - & - \\
Acetate & - & - \\
Succinate & - & - \\
Citrate & - & - \\
\hline
\end{tabular}

* $\quad+$, positive; - , negative; $\mathrm{v}$, variable between strains

** Bacto-Casamino acids (Difco.).

acetate, succinate and citrate were not utilized for growth.

\section{$\% G C$ of $D N A$}

The guanine-plus-cytosine $\mathrm{mol} \%$ of the DNA was estimated to be 59.2 .

\section{DISCUSSION}

The fact that the cells of the bacterium were aerobic, Gram-positive and spore-forming rods indicates that the organism should be classified in the genus Bacillus.

Limits of temperature and of $\mathrm{pH}$ for growth were $45 \sim 70^{\circ} \mathrm{C}$ and $2.0 \sim 5.0$, respectively, and it grew with glucose, galactose, starch, glycerol and Casamino acids as the sole source of carbon and energy, but not with ethanol, sorbitol, acetate, succinate or citrate. Growth occurred with ammonium salt but not with nitrate as the nitrogen source. No growth factors were required for growth of the organism. These results were identical with those of $B$. acidocaldarius, ${ }^{4)}$ and the $\mathrm{GC} \mathrm{mol} \%$ of DNA (59.2) was close to that of the latter (61 62).

Based on the bacterial properties mentioned above, Bacillus sp. 11-1S can be identified as Bacillus acidocaldarius Darland and Brock. ${ }^{3,4,11)}$

\section{REFERENCES}

1) F. Uchino, Agric. Biol. Chem., 46, 7 (1982).

2) F. Uchino and T. Nakane, Agric. Biol. Chem., 45, 1121 (1981).

3) R. E. Buchanan and N. E. Gibbons (ed.), "Bergey's Manual of Determinative Bacteriology," 8th Ed., The William \& Wilkins Co., Baltimore, 1974, p. 550.

4) G. Darland and T. D. Brock, J. Gen. Microbiol., 67, 9 (1971).

5) F. Uchino and S. Doi, Agric. Biol. Chem., 31, 817 (1967).

6) P. Gerhardt et al. (ed.), "Manual of Methods for General Bacteriology," American Society for Microbiology, Washington D.C., 1981.

7) H. Saito and K. Miura, Biochim. Biophys. Acta, 72, 619 (1963).

8) G. G. Markov and I. G. Ivanov, Anal. Biochem., 59, 555 (1974).

9) P. Cashion, M. A. Holder-Franklin, J. McCully and M. Franklin, Anal. Biochem., 81, 461 (1977).

10) M. Fujimoto, A. Kuninaka and H. Yoshino, Agric. Biol. Chem., 38, 777, 785, 1555, 2141 (1974).

11) V. B. D. Skerman, V. McGowan and P. H. A. Sneath, Approved list of bacterial names. Int. J. Syst. Bacteriol., 30, 256 (1980). 